\title{
REFORM OF THE HUNGARIAN CODE OF CIVIL PROCEDURE WITH SPECIAL REGARD TO RULES OF TAKING EVIDENCE ${ }^{1}$
}

Nagy Adrienn

\section{INTRODUCTION}

The Hungarian Parliament has adopted three new procedural acts not so long ago: Act CXXX of 2016 on the Code of Civil Procedure (hereinafter: Code of Civil Procedure), Act I of 2017 on the Code of Administrative Court Procedure (hereinafter: Code of Administrative Court Procedure) and Act CL of 2016 on Administrative Proceedings, which all entered into force on 1 January 2018. These new procedural acts followed the recodification of many substantive laws such as the Civil Code and the Criminal Code. But this paper aims to give a general overview of the codification of the Code of Civil Procedure, summarize the most important change in the course of civil proceedings and emphasize the new institutions of taking evidence in civil cases.

\section{History of the Codification}

The Hungarian Government in its Government Decree 1267/2013 (V.17) on Codification of Civil Procedure initiated to start works on a comprehensive modernisation of civil procedural law, namely the Act III of 1952 on the Code of Civil Procedure. The immediate objective of this review was to create a modern civil procedural code corresponding international practice and standards, which ensures effective operation of substantive laws. An additional purpose was, that the new Civil Procedure Code, based on the results of jurisprudence and legal practice, shall regulate civil procedural relations in a perspicuous and coherent manner, attentively to technological achievements, thus making the situation of professionals and citizens seeking for legal advice easier. The role of the new Code of Civil Procedure is outstanding, since the Act V of 2013 on the Civil Code re-regulated substantive civil relations and the strengthening of substantial law falls within the scope of civil procedure code. The original deadline of shaping the text of new

\footnotetext{
1 The described article was carried out as part of the EFOP-3.6.1-16-00011 "Younger and Renewing University - Innovative Knowledge City - institutional development of the University of Miskolc aiming at intelligent specialisation" project implemented in the framework of the Szechenyi 2020 program. The realization of this project is supported by the European Union, co-financed by the European Social Fund.
} 
Code of Civil Procedure, and submitting it to the Government was the fourth quarter of 2016.

Codification works were running multi-threaded, and the most essential elements and results of that can be summarised as follows. The Government on its meeting, took place on $14^{\text {st }}$ of January in 2014, accepted the Conception of New Code of Civil Procedure (hereinafter: Conception), in which it laid down the statutory regulatory objectives and basic principles to be implemented. In May 2015, on the basis of Government Decree 1267/2013 (V. 17) 14, a Working Committee had been set up to draw up the proposal for text of the new Code of Civil Procedure in line with the principles laid down in the Concept. From the October 2015, an Expert Committee was set up within the framework of Ministry of Justice, which shall finalise the text of the new Code of Civil Procedure, make the final decision on uncompleted professional disputes, and discuss professional materials supplied by Working Committees.

After a three-years long preparatory process, The Hungarian Parliament adopted the new Code of Civil Procedure on 22 November 2016. The Code replaced the Act III of 1952 on the Code of Civil Procedure, which served 65 years the basic point of reference for all litigious and non-litigous civil and administrative court cases. The new Code of Civil Procedure shall be applied in civil proceedings initiated on or after 1 January $2018 .^{2}$

\section{Reform of Administrative Court Procedure}

The Code of Administrative Court Procedure brought some notable changes. In fact, this Code's existence as a separate act is in itself an innovation, since before the rules of administration litigation were incorporated into the Act III of 1952 on the Code of Civil Procedure.

The Code of Administrative Court Procedure's stated goal is to provide an "unbroken" system of judicial protection, where full review of administrative decisions by the courts is possible in all cases. The Code also foresees a situation where an administrative authority has infringed the law by failing to perform certain actions, rather than by adopting an unlawful decision.

The Code aims to increase the timeless of administrative proceedings and litigation. It does so, inter alia, by giving courts broader powers to modify administrative decisions rather than just referring the case back to the administrative authority.

\footnotetext{
2 Polgári eljárásjog I / A. Nagy, Z. Wopera (editors). Budapest: Wolters Kluwer, 2017. P. 25-27.
} 
As the final step of the reform of the central administration, the Hungarian Parliament adopted the Act CXXX of 2018 on Administrative Courts. According to the original text, the Act would enter into force on 1 January 2020, but the Parliament postponed its entry into force for an indefinite period. The goal of the new legislation was to "restore the prestige of the administrative courts" which was abolished in 1949 in Hungary. Since then no separate administrative court system existed, it was integrated first into the civil courts, later into the labour courts.

The reason for the separation was that administrative law has a different internal logic compared to the civil law. Government experts expect that the new system will be capable of contributing to the development of administrative law and jurisprudence, and outbalancing the dominant position of the public administration in the litigation proceedings.

The legislation sets up 8 regional administrative courts and the "administrative high court". According to the reform, each act of the Hungarian administration that has a legal effect can be challenged, but only before the administrative courts. The regional courts proceed at first instance and the high court proceeds on appeal. In some cases however, for example in proceedings concerning referendums and election procedures, the latter proceeds at first instance. ${ }^{3}$

\section{Substantial changes in rules of civil proceedings}

The Code of Civil Procedure diverges from the previous system of civil proceedings conceptually, as well as in respect of several general and specific provisions. ${ }^{4}$ It would be difficult to show all of these changes in this paper, therefore we only highlight the changes we deem the most substantial.

\subsection{Effective trial - Concentrated procedure}

The most important legislative aim of the new Code of Civil Procedure was to reach and protect effective trial in the Hungarian system. This means, that criteria of a concentrated procedure shall be achieved systemwide, from the specific principles of civil procedure over the rules of first instance and remedy. Marks of concentration principle could be evidenced in the following legal institutions.

\footnotetext{
3 See more : Rozsnyai K. Current Tendencies of Judicial Review as Reflected in the New Hungarian Code of Administrative Court Procedure. Central European Public Administration Review. 2017. № 1. P. 7-23.

4 Wopera Z. Az új polgári perrendtartás elvi alapjai. Jogtudományi Közlöny. 2017. № 4. P. $153-154$.
} 
The Code of Civil Procedure has a chapter for principles. Only those principles are in this unit, whose have influence over the entire Code, briefly, sentenced, on high level of abstraction, like in the first book of new Hungarian Civil Code. ${ }^{5}$ New principles appear, like concentration of proceedings, the parties' obligation to facilitate the proceedings and speak the truth. The parties increased procedural responsibility in respect of move forward the proceeding, which is one of the pillars of concentrated trial, could be guaranteed by these theoretical rules. But the new Code requires the court to invest oneself in another character, namely by the involvement principle $^{6}$ and court's duty to manage the case. This active involvement does not override the right of disposal of the parties, rather it plays an active role in the effective enforcement of their right: the court shall actively contribute to let the parties know what they shall do to close the trial as soon as possible. ${ }^{7}$

\subsection{Division of the trial}

The rules of first instance in the new Code of Civil Procedure were fundamentally reformed, as division of the trial was introduced. For this it was necessary that the rules of first instance shall prescribe strict deadlines, and expect increased obligations from the parties. In a divided trial the procedure has two parts: preliminary hearing and trial on merits (or main hearing). Preparatory hearing is stressful because of the appropriate preparation for the main hearing: this period is concentrate on setting up the content and frame of the dispute, for which the Law shall provide an exact "scenario" in a mood to ensure the balance between oral and written acts too. Written preparation is followed by an oral hearing where the parties' statements of facts and laws, referrals, motions of proof are recorded, by means of the judge's case management (when required). Preliminary hearing ends with an authorisation to proceed, which has a very important consequence, the preclusion: the court shall exclude the statements and motions of the parties stated after that stage. In its final order the court opens the main hearing, set the hearing on merits, on which only the taking of evidences is obtained.

\footnotetext{
5 Polgári eljárásjog I / A. Nagy, Z. Wopera (editors). Budapest : Wolters Kluwer, 2017. P. 35.

6 With a view to ensuring the concentration of proceedings, the court shall, in the manner and using the means specified in this Act, contribute to enabling the parties to perform their procedural obligations: The court's duty to manage the case. Section 6. Hungarian Code of Civil Procedure.

7 Vitvindics M., Wopera Z. Az új polgári perrendtartás koncepciójának sarokkövei. Fontes Iuris. 2015. № 1. P. 48.
} 


\subsection{The model of professional case management}

The model of professional case management rules causes essential changes of the trial of first instance. The Code of Civil Procedure keeps both input levels for the first instance, in line with the solution applied in the vast majority of European civil procedures, but the rules of first instance basically modelled to the regional court, and the different rules applied in district courts seemed to be only derivations of general rules. According to that, main innovation is the introduction of mandatory legal representation in general expect in a few cases tried before district courts, where litigants without legal representation are aided by the use of standard forms and templates, as well as the more active role of the judge.

\subsection{Reform the rules of remedies}

The re-regulation of remedial system had dual objective: let the right to legal remedy guaranteed by international instruments and the Fundamental Law of Hungary prevail, at the same time the regulation shall be in accordance with the strict deadlines of first instance, and do not let delay the proceeding. In this spirit the rules of redress and extraordinary appeals were reformed, in which the minimisation of cases of abolition of judgements had an important role. ${ }^{8}$

\subsection{New form of collective claims - Associated actions}

The Code of Civil Procedure regulates a new form of collective claims, using an opt-in system, where the court rules on one so-called "representative claim" by a private person. The condition for this is that all claimants must enter into a so-called "collective claim agreement" in which they must regulate the legal relationship between the parties. This type of collective claim can be used in consumer protection cases and certain labour and environmental disputes. In an associated action, at least ten plaintiffs may enforce one or more rights, the content of which is identical regarding all plaintiffs (hereinafter "representative right"), provided that the facts serving as grounds for the representative right are substantially identical regarding all plaintiffs (hereinafter "representative facts"), and the court permits the associated action. ${ }^{9}$

\footnotetext{
8 Osztovits A. The Legal Remedy System of the Hungarian Civil Procedure Code: Changes int he Act ont he new Hungarian Code of Civil Procedure. Hungarian Journal of legal Studies. 2017. № 1. P. 93-105.

9 Subsection (1) of Section 583 of Code of Civil Procedure; see more : Collective Redress as New Institution of Civil Procedure Code and Its Applicability to Protect Environment / B. Tóth. Journal of Agricultural and Environmental Law. 2017. № 23. P. 182-193.
} 


\subsection{Electronic communication and using modern technique}

In the Hungarian Code of Civil Procedure it is essential to examine the electronic communication and using results of modern technique. These rules have preliminaries because the Act III of 1952 on the Code of Civil Procedure prescribed from 1st of July 2016 the obligatory electronic communication for specific legal entities in legal proceedings, furthermore the audiovisual hearing was embodied as an innovation. These rules also appear in the new Code of Civil Procedure expanding the scope of application.

\section{The rules of taking evidence}

New institutions were introduced between the rules of taking evidence too. The rules concerning taking evidence were restructured in the Code, abolishing the fragmentation caused by recent legislative amendments and eliminating doctrinal contradictions. For example, the principle of free determination of the facts alternates the principle of freedom of evidences, and the interest in burden of proof changes the term of burden of proof. During the creation of new rules simplification, and raising the results of related jurisprudence to a standard level of norms also played an important role. New legal institutions appear: the situation of incapacity to proof, the rule of unlawful means of taking evidence and the using the results of taking evidence carried out in other proceedings.

\subsection{The principle of establishing the factual situation freely}

Section 263 of the Code of Civil Procedure rules the principle of establishing the factual situation freely in connection with taking of evidence: unless otherwise provided by an Act, the court shall not be bound by any formal rule or specific method of taking of evidence, or by the use of specific means of producing evidence; for establishing the factual situation. This basically corresponds to the principle of the freedom of proof, however in some exceptional cases the probative force of a means of proof may be defined in advance.

In a free system of evidence it is within the court's discretion to decide what means of proof it is going to use in order to establish the facts and what methods of proof it considers appropriate to apply in the given case. In a free system of evidence the law gives the court discretion to assess the probative force of the individual pieces of evidence. ${ }^{10}$

10 Harsági V. Evidence in Civil Law - Hungary. Maribor, Slovenia : Lex Localis, 2015. P. 15. 
The principle of establishing the factual situation freely is broader than the freedom of proof ruled in Code of Civil Procedure of 1952. Party shall prove his presentation and facts during the proceeding; the party's own presentation cannot be evidence. The party's presentation shall be supported by other evidence, if successful, the court may freely use the parties' presentations to establish the facts. The new Code of Civil Procedure thus expresses more firmly that the party's personal statement cannot be assessed as evidence.

In the system of free evidence, there are external limits caused by legal presumptions and fictions, on the other hand, the guarantee rules of methods of taking evidence, and thirdly, the statutory rules which exceptionally require the use of certain methods of taking evidence (for example in actions on custodianship the court shall appoint a psychiatric expert for the examination of the defendant's mental state). ${ }^{11}$

The absolute limit of the principle of establishing the factual situation freely can be found in Section 264 of Code of Civil Procedure: If the property law consequences of a criminal offence adjudicated with final and binding effect are to be assessed in civil proceedings, the court shall not be entitled to establish in its decision that the convicted person did not commit the crime for which he was convicted; and a court proceeding in a matter falling within the scope of Code of Civil procedure shall be bound by a final and binding decision adopted by an administrative court regarding the legality of administrative activities.

The principle of establishing the factual situation freely is linked to the rule in Section 263 subsection (2) of Code of Civil Procedure: In the course of adopting its decision, the court shall not be bound by any decision adopted by another authority, nor by any disciplinary decision, nor by the factual situations established in such decisions.

\subsection{Incapacity to proof}

The title of Section 265 of the new Code of Civil procedure is Interest to prove and incapacity to prove. The Act III of 1952 on the Code of Civil Procedure did not regulate the situation of incapacity to prove. To understand these rules, it is important to present the principle of the parties' obligation to facilitate the proceedings according to Subsections (1) - (2) of Section 4.

\footnotetext{
11 Pomeisl A. A tényállás szabad megállapításának elve. Kommentár a polgári perrendtartásról szóló : törvényhez, évi CXXX. 2016 / Z. Wopera (ed.). Budapest : Magyar Közlöny Press, 2017. P. 468-469.
} 
The parties shall bear the burden of presenting the relevant facts of the case and submitting the respective supporting evidence. The parties bear strict responsibility to fulfil these obligations, so it was reasonable to rule the situation of incapacity to prove. ${ }^{12}$

The relevant facts in a case shall be proven by the party having an interest in the fact being accepted by the court as the truth (hereinafter "interest to prove"), and the consequences of not proving or unsuccessfully proving such a fact shall be borne by the same party (unless otherwise provided by an Act). A party shall be considered to be in incapacity to prove, if he substantiates that:

a) the data indispensable for his motion to present evidence are in the exclusive possession of the party with opposing interests, and he certifies that he took the necessary measures to obtain such data;

b) it is not possible for him to prove a statement of fact, but it can be expected that the party with opposing interests will supply evidence of the non-existence of the facts stated, or

c) the success of taking evidence was frustrated due to the fault of the party with opposing interests,

and the party with opposing interests does not substantiate the opposite of those specified in points a) to c).

If there is incapacity to prove, the fact to be proven by the party affected by such incapacity may be accepted by the court as the truth, if it does not have any doubt regarding its veracity.

According to József FARKAS incapacity to prove is signal instance of probability: the party is able to present the relevant facts of the case but not able to submit the supporting evidence, but the relevant facts are supported by other details of the case..$^{13}$

The situation of incapacity to prove occurs rarely in practice just in cases of asymmetric possession of evidence, for example in wrong medical treatment cases.

\subsection{Unlawful means of taking evidence}

Unlawful means of taking evidence is also a new legal institution in Section 269 of Code of Civil Procedure. Important question: parties are

12 The rules of incapacity to prove are well-known in German Code of Civil Procedure (Zivilprozessordnung). A törvény hatálya és az alapelvek / Z. Wopera (ed.). A polgári perrendtartásról szóló 2016. évi CXXX. törvény magyarázata / Z. Wopera (ed.). Budapest : Wolters Kluwer, 2017. P. 24-27.

13 Farkas J., Kengyel M. Bizonyítás a polgári perben. Budapest : KJK-KERSZÖV Press, 2005. P. 61-62. 
permitted of using secret videos, photos, hacked e-mails etc. in civil proceedings as evidence ${ }^{14}$

The Code of Civil Procedure of 1952 did not formulate generally applicable clauses of using unlawful evidence. Prohibitions were concentrated around the witness statement and expert opinion, but in other areas the lack of general and special prohibitions resulted in uncertainty concerning such illegalities arising out of litigation as for example the stealing of documents or obtaining an electronic letter through unauthorised access to the e-mail system. In the Hungarian legal literature Farkas regarded evidence obtained unlawfully - through the violation of personal rights actually - to be admissible (for example a stolen letter). Székely objected to the admissibility of evidence obtained through the violation of personal rights. Gáspárdy regarded it as part of the ethos of the free evidentiary system that unlawfully obtained evidence could not be used during the action. ${ }^{15}$ Kengyel believed that the principle of relativeness should be applied to use unlaw fully obtained evidence in civil proceedings. This means that the proceeding court shall decide whether the unlawfulness of the evidence is comparable to the act of opposing party in certain case. this discretion cannot be described by rules of an act, but it should be excluded from the scope of the unlawful evidence to commit crimes and violation of personal rights and the evidence thus obtained should not be used under any circumstances. ${ }^{16}$

Subsection (1) of Section 269 of the new Code of Civil Procedure determines the concept of unlawful means of taking evidence: A means of proof, or any separable part of it, shall be unlawful and shall not be used in the action, if:

a) it was obtained or produced by violating or threatening a person's right to life and physical integrity (for example defeat the holder of document evidence and remove the document from him);

b) it was produced by any other unlawful method (for example video made in secret);

c) it was obtained in an unlawful manner(for example someone steals the document evidence), or

\footnotetext{
14 See more : Grád A. Lesben álló bizonyítás - a titkos felvételek felhasználhatósága a bírósági eljárásban. Családi Jog. 2016. № 3. P. 25-31.

15 Harsági V. Evidence in Civil Law. Hungary, Maribor, Slovenia : Lex Localis, 2015. P. 39.

16 Farkas J., Kengyel M. Bizonyítás a polgári perben. Budapest : KJK-KERSZÖV Press, 2005. P. 144
} 
d) its submission to the court would violate personality rights (workplace under video surveillance, but the employee does not contribute to the use of video in civil proceeding).

Generally parties are forbidden to use unlawful proof in the civil actions. Parties are absolutely forbidden to use a means of proof, if it was obtained or produced by violating or threatening a person's right to life and physical integrity.

With the exception of the absolutely forbidden case, the unlawful means of proof may be taken into account by the court exceptionally and considering the following circumstances:

a) the specifics and extent of the violation of law;

b) the legal interest affected by the violation of law;

c) the impact of the unlawful piece of evidence on discovering the factual situation;

d) the weight of other available pieces of evidence, and

e) all other circumstances of the case. ${ }^{17}$

If an unlawful means of proof cannot be used and the party proving a relevant fact in the case cannot prove it in any other way, the court shall apply the rules pertaining to the incapacity to prove.

If the unlawful means of proof was taken into account by the court, the rules of Code of Civil Procedure do not exempt the party from other legal liability. The party shall also take this rule into consideration before proposing using secret video. The party with opposing interests may, for example, initiate civil proceeding by reason of violation of personal rights.

Applying Section 269 of Code of Civil Procedure the Curia's decision BH2015.38 shall to be taken into account. In a parental custody case, the secret video filed by the plaintiff - whose purpose was to support the defendant's incapacity for custody - was excluded from the evidence by both the court of first and second instance and the Curia in review proceeding. Referring to the case-law, the Curia has emphasized that secret video should not be excluded from the evidence because it was created in an unlawful manner. However, judicial practice usually requires an additional factual element: secret video can only be used as evidence in civil proceedings if only this means of proof can establish the fact in question. In general, therefore, there is no obstacle for the plaintiff to prove the inability of the defendant to bring up a child by secret video recording. However, this was not the case, the testimony of the witnesses, the opinion of the psychologist's expert, and the personal hearing of the defendant was also suitable for establishing

17 Subsection (4) of Section 269 of Code of Civil Procedure. 
the facts by the court. Therefore, the Curia also exclude the secret video from the evidence.

The Hungarian Constitutional Court has also examined the question of the use of unlawful evidence in civil cases. In Decision No 3312/2017 (XI. 30) the Court came to the conclusion that the assessment of unauthorized e-mail correspondence as evidence does not constitute a breach of the Fundamental Law if the party can only prove that the opposing party planned the unlawful transfer of children abroad.

\subsection{Using the results of taking evidence carried out in other proceedings}

Several times the same relevant facts shall be proven in different proceedings, for example in criminal, infringement, administrative proceedings ect. Multiplication of the same takinge vidence in different proceedings is contrary to the requirement of economic litigation and principle of litigation in reasonable time. For this reason Section 270 of Code of Civil procedure allows the using the results of taking evidence carried out in other proceedings.

The court may use evidence obtained in other proceedings, including statements of fact made by a party in other proceedings, unless the method of taking evidence, apart from the characteristics of those proceedings, is in violation of the provisions laid down in this Act. The court examines, at request, the obstacle to using a piece of evidence, unless it is obvious. If a party is stating that a piece of evidence obtained in another proceeding may not be used, he shall bear the burden of proof in this respect.

A typical example of applying this rule: the party suggests in civil proceeding that the court should take into account the expert opinion made in previous criminal proceeding.

\subsection{Reform of expert evidence}

Expert evidence rules have also changed significantly. The purpose of the new rules was to create a harmony between the rules of expert evidence and the principles of civil procedure, in particular the principle of free disposition. Another important reason for renewing the rules was that an effective system of expert evidence could facilitate the completion of civil litigation within a reasonable time. ${ }^{18}$

Practical problems related to expert evidence should not be sought primarily in the sections of procedural law. In parallel with the codification

18 Conception of New Code of Civil Pocedure (2014.01.14.). 20 p. 
of the Code of Civil Procedure, a reform of the rules governing the operation of judicial experts had been carried out, resulting in the adoption of the Act XXIX of 2016, which came into force in 2017. So the rules of Code of Civil Procedure had to be adapted to the norms regulating renewed expert activity.

The new Code of Civil Procedure did not change the expert's role in civil proceedings compared to the previous law:

- expert evidence is one of the methods of taking evidence;

- expert is one of the means of proof;

- expert opinion is evidence. ${ }^{19}$

It is important to emphasize this because, during codification, there was an initiative that would have changed the role of the expert in civil cases and would have qualified it as the assistant of the judge. ${ }^{20}$

The innovation in expert evidence is that the parties are entitled to provide an expert opinion in two ways: by a party-appointed expert (private expert) or by a court-appointed expert. The new Code of Civil Procedure therefore, it institutionalized the evidence of private experts as the most significant novum of regulation.

The Code stipulated that the opinions of a party-appointed expert and the court-appointed expert have the same evidentiary value. The procedural law does not make any distinction as to the personality of the expert: a party-appointed expert can be the same person as a courtappointed expert.

Party-appointed and court-appointed expert have the same procedural rights and obligations. Although the Code of Civil Procedure imposes additional obligations on party-appointed expert in Section 303, these also serve to provide the basis for opinion on all relevant information as in the case of an opinion of court-appointed expert. There are three fundamental differences between the two methods of expert evidence:

- The court does not intervene in party-appointed expert evidence, the parties have the right to dispose of it, and the Code also puts more demands on the parties in the course of expert evidence than otherwise in general during the proceeding;

- In the case of party-appointed expert evidence, two expert opinions are allowed to be submitted simultaneously for the same subject matter, as party-appointed expert can be used by both parties. This allows for a multi-

\footnotetext{
19 Sections 267-268 of Code of Civil Procedure.

20 Aszódi L. Szakértők. A polgári perrendtartásról szóló 2016, évi CXXX, törvény magyarázata I Z. Wopera (ed.). Budapest : Wolters Kluwer, 2017. P. 403.
} 
facted approach to the expert opinions, so that even the concurrent nature of the evidence acts does not compromise the effectiveness of the proceeding;

- The Code of Civil Procedure sets the order of methods of employing an expert in promoting the effectiveness of proceeding: the employment of a court-appointed expert is only possible if the parties do not want to or not able to employ a party-appointed expert.

The court-appointed expert is a good solution for a party who is unable to provide professional case management which is necessary for party-appointed expert evidence, or who cannot afford a private expert. In certain cases, an act may prohibit the employment of party-appointed expert, for example in non-litigious civil cases or in preliminary taking of evidence.

According to the rules of Code of Civil Procedure, expert evidence is usually carried out as follows. The party presenting the evidence shall file a motion to present expert evidence as early as possible, but generally in preparatory stage of the proceeding. In the motion to present expert evidence the party shall specify the fact to be proven and the method of employing the expert: party-appointed expert or court-appointed expert. If the party moves for the submission of an expert opinion prepared by an expert appointed by him, and the court orders the taking of expert evidence, the opinion of party-appointed expert shall be submitted within the time limit set by the court. There is no need for judicial action on the advance payment of the expert fee, since the party pays the fee directly to the expert. Questions to be answered by the expert are also formulated by the party and presented to the expert. There is no direct communication between the court and party-appointed expert.

If the party files a motion to present party-appointed expert evidence, the opposing party is also entitled to submit an opinion of another partyappointed expert. If the party files a motion to present court-appointed expert evidence, the opposing party is not allowed to mandate a private expert.

Of course, we are not able to undertake to present all the procedural aspects of new rules of expert evidence in this study. The aim of the new rules was to create conditions where high-quality expert opinion can be submitted in a short time. The new Code of Civil Procedure has also attempted to solve the financing problem of judicial experts. 


\section{CONCLUSIONS}

Since the entry into force of the new Code of Civil Procedure, there has been little time to give a comprehensive assessment of its practical application. The legislator has made systematic change in the rules of civil proceedings to improve the efficiency of litigation.

The first statistics are positive: the number of pending civil lawsuits has decreased significantly: there were 144950 litigious proceedings in progress in 2017, which fell to 109096 in 2018, this means decrease of $25 \%$. $^{21}$

It should also be added that the number of litigious cases has decreased, lawyers need probably more time to prepare for professional case management. The number of civil proceedings decreased by $20,6 \%$ in $2018 .{ }^{22}$

\section{Information about author:}

Nagy Adrienn,

Ph. D., Associate Professor, Head of Institute of European and International Law

Faculty of Law University of Miskolc Miskolc, 3515, Hungary

DOI https://doi.org/10.30525/978-9934-588-43-3/1.8

\footnotetext{
${ }^{21}$ URL: https://birosag.hu/sites/default/files/2019-05/ugyforgalom_2018.ev_szerkesztett_ foly_v.pdf.

22 URL: https://birosag.hu/sites/default/files/2019-05/ugyforgalom_2018.ev_szerkesztett foly_v.pdf.
} 